Article

\title{
Epidemiological and Clinical Profiles of Acute Diarrhea Due Rotavirus or Associated Rotavirus and Other Pathogens in Children Aged 0-71 Months Hospitalized at Kalembe-lembe Pediatric Hospital in Kinshasa, Democratic Republic of the Congo
}

\author{
Clément M. Mbadiko ${ }^{1}$, D. Mutambel Hity S.N ${ }^{2}$, Gracia K. Mbuyi ${ }^{3}$, Erick Bukaka ${ }^{1}$, Ruth Claudine Tshiama ${ }^{1}$, \\ Gédéon Ngiala Bongo ${ }^{1, *(B)}$
}

How to cite this paper: Mbadiko, C. M., Hity S.N, D. M., Mbuyi, G. K., Bukaka, E., Tshiama, R. C., \& Bongo, G. N. (2021). Epidemiological and Clinical Profiles of Acute Diarrhea Due Rotavirus or Associated Rotavirus and Other Pathogens in Children Aged 0-71 Months Hospitalized at Kalembe-lembe Pediatric Hospital in Kinshasa, Democratic Republic of the Congo. Global Journal of Epidemiology and Infectious Disease, 1(1), 66-80. Retrieved from https://www.scipublications.com/journal/index.php/gjeid/article/view/165

Received: October 20, 2021 Accepted: November 21 , 2021 Published: November 22, 2021

Copyright: (c) 2021 by the authors. Submitted for possible open access publication under the terms and conditions of the Creative Commons Attribution (CC BY) license (http://creativecommons.org/licenses /by/4.0/).
${ }^{1}$ Department of Biology, Faculty of Sciences, University of Kinshasa, Kinshasa, Democratic Republic of the Congo

${ }^{2}$ Department of Biology, Faculty of Sciences, National Pedagogical University, Kinshasa, Democratic Republic of the Congo

${ }^{3}$ Teaching and Administration in Nursing Care, Nursing Science, Higher Institute of Medical Techniques, Kinshasa, Democratic Republic of the Congo

*Correspondence: gedeonbongo@gmail.com; gedeon.bongo@unikin.ac.cd

Abstract: This research is based on a retrospective analysis of medical records filed in the archives of the emergency departments of Kalembe-lembe Hospital in Kinshasa city in the Democratic Republic of the Congo. The study involved 324 records of patients aged 0-71 months admitted to the emergency departments and hospitalized for acute diarrhea from January 1 to December 31, 2015. The aim was to inventory the cases of rotavirus diarrhea and/or other germs (individually or in combination) to study their epidemiological and clinical aspects. Thus, the epidemiological and clinical parameters (age, sex, season, symptoms, frequency and physical aspects of stools, dehydration status and duration of hospitalization) of diarrheic children diagnosed as positive for rotavirus were compared with those infected with other germs (individually or in combination with rotavirus or other viruses). The search for the etiological agents of the diarrhea was performed in $56.48 \%$ of the cases. The results of this work allowed us to show: (i) a predominance of infections by viruses $(69.94 \%)$ including rotavirus $(48.08 \%$ ), (ii) high rates of infections by etiological agents of diarrhea including rotavirus in children under 12 months, (iii) a high proportion of vomiting, fever, physical asthenia and restlessness or frequent and liquid stools or moderate dehydration in children infected with rotavirus, (iv) specific clinical pictures according to the etiological agents of diarrhea or their combinations.

Keywords: Epidemiology, Clinical profile, Acute Diarrhea, Rotavirus, Other pathogens, Democratic Republic of the Congo

\section{Introduction}

Acute childhood diarrhea is a global public health problem because it is responsible for significant mortality in developing countries [1]. According to the World Health Organization (WHO), 1.5 million children died from acute diarrhea worldwide in 1999; this is significantly lower than the figure reported in 1980, which reported 4.6 million deaths [2]. Diarrhea is one of the leading causes of child mortality, especially among children 
under 5 years of age [2]. In developed countries, acute diarrhea causes 3 to 4 million medical consultations and is the second leading cause of childhood hospitalization, with 7 to $10 \%$ of hospitalizations before the age of five. The annual incidence of acute childhood diarrhea in these countries is estimated between 1.3 and 2.3 episodes per child [2-4]. Meanwhile in developing countries, diarrhea is a major cause of mortality and morbidity (1.4 to 2.5 million deaths in 2000), with an annual incidence of 3 to 9 episodes per child $[2,5,6]$, corresponding to 2 to 4 times more than among children in developed countries. Children under 5 years of age have 1.5 annual episodes of acute diarrhea [6]. Among the main infectious causes of acute diarrhea, viruses namely rotavirus are important [1,7].

Globally, rotavirus constitutes the cause of $37 \%$ of diarrhea deaths in children under five years old. It causes more than 450,000 deaths each year, with nearly $95 \%$ of rotavirusrelated deaths occurring in developing countries where access to treatment is limited or non-existent [6]. Rotaviruses cause up to $25 \%$ of diarrheal episodes in children aged 6-24 months; this diarrhea, usually watery, is accompanied by vomiting and fever [8-9]. Kabuya et al., [1] revealed that rotavirus was responsible for $25 \%$ of dehydration mortality in Kinshasa [10]. Rotaviruses are most implicated in viral gastroenteritis in young children. About $90 \%$ of rotavirus infections occur before the age of two years [4,5,11]. Many studies have shown the important role of rotavirus as a cause of diarrhea in children in both developed and developing countries, most of which have occurred in children under five years of age $[4,7,12,13]$. Rotavirus is a public health problem in developing countries, where all children under the age of two to three are infected. A similar observation is made in developed countries where, however, hygienic conditions are good. The incidence of rotavirus is almost similar in developed and developing countries and varies from one country to another or even within the same country, region to region $[14,15]$.

Kabuya et al. [1] confirmed that rotavirus is a major cause of hospitalization for acute gastroenteritis in infants living in Lubumbashi in the Democratic Republic of the Congo (DRC). They also reported that rotavirus diarrhea was 6 times more likely to lead to moderate or severe dehydration i.e. children infected with rotavirus were twice as likely to have stools more than six times a day than those infected with other microorganisms. Furthermore, it should be noticed that vomiting, fever and lethargy characterize rotavirus infection.

Several studies report a correlation between seasonal distribution and rotavirus infection in a population. Indeed, rotavirus infections appear to occur mainly during cold season periods (dry season in tropical countries and winter in temperate countries) [11, 16-19].

The aim was to describe the epidemiological and clinical characteristics of children with acute rotavirus diarrhea or their association with other causative agents of diarrhea, and to assess whether rotavirus infection or rotavirus and other germs are a major risk factor for dehydration (moderate or severe) associated with stool frequency in these children.

\section{Materials and Methods}

\subsection{Study design}

This research is a retrospective analytical study of the medical records from the emergency records of Kalembe-lembe Pediatric Hospital in Kinshasa city (DRC) between January 1 and December 31, 2015.

\subsection{Study population}

As inclusion criteria, the study carried out concerns children aged 0-71 months hospitalized at the Kalembe-lembe paediatric hospital for acute diarrhea. Excluded from this research were children over 71 months of age, ambulatory patients, incomplete or unusable patient records. 


\subsection{Sample size}

The search for causative agents of acute diarrhea in hospitalized patients was conducted in 183 children (56.48\%) out of 324 hospitalized children in a population of 337 identified children. In addition, although the study is limited to children interned at the Kalembe lembe pediatric hospital, Fisher's statistical relationship indicates that this representative sample size is greater than 164 expected patients. It makes it possible to generalize the results to the population of children aged 0-71 months hospitalized in other health facilities in Kinshasa. This study described the epidemiological and clinical characteristics of acute rotavirus diarrhea or the association of germs and assessed its impact on certain clinical parameters: frequency and appearance of stool, dehydration status, etc.

\subsection{Parameters studied}

This research was based on the following approach:

- Inventory the number of cases of acute rotavirus diarrhea;

- Identify epidemiological (age, sex, seasonality, mortality rate), clinical (frequency and aspects of stool, clinical signs associated with diarrhea, dehydration status), etiological (isolated pathogens) and progressive (duration of hospitalization and complications) characteristics in children 0-71 months of age hospitalized at Kalembelembe Hospital, Kinshasa (DRC).

For ethical reasons, the identity of the patients of which consultation records were the subject of this study was kept confidential.

\subsection{Data collection}

Data were collected after sorting the medical files (patient records) archived in the movement and statistics section service, using an individual survey form. The study involved 324 children aged 0-71 months admitted to the emergency department and hospitalized at the Kalembe-lembe pediatric hospital for acute diarrhea [20].

Data analysis was performed with respect to age, season, month, diarrhea characteristics (appearance and frequency of stool), dehydration status, clinical signs associated with diarrhea, isolated etiological agents, duration of hospitalization, complications that occurred. The idea was to establish and compare epidemiological-clinical profiles of acute rotavirus diarrhea cases with those of diarrhea due to other pathogens or the association of causative agents of diarrhea.

\subsection{Data analysis}

Data collected were analyzed using Microsoft Excel 10 (2010) software. The measures of association between different qualitative variables in the study were evaluated by the Chi-square test ( $\mathrm{p}$-value $\leq 5 \%$ ) and the frequency of the class average. The data analysis was performed using the R software (version 3.2.2).

\section{Results}

\subsection{Epidemiological parameters}

\subsubsection{Distribution of patients by admission period}

The monthly distribution of acute diarrhea cases among children aged 0-71 months in 2015 (Figure 1) at Kalembe-lembe Hospital shows a predominance of patients in June and September, two months that do not belong to the same climatic season. 


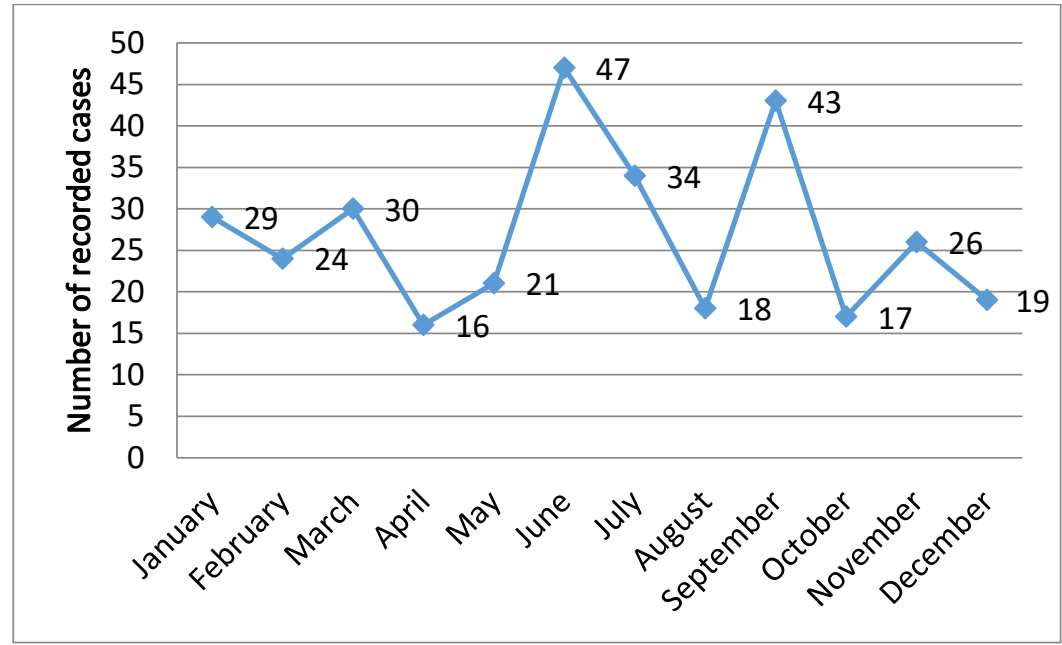

Figure 1. Monthly distribution of acute diarrhea cases reported in 2015 at Kalembe-lembe Hospital.

It is observed that there are three peaks spaced 2 months apart that are higher than the annual average: peaks in March (30 cases), June (47 cases) and September (43 cases). The peaks in June and September are indicative of the changing seasons; indeed, the peak in June corresponds to the beginning of the dry season (cool temperatures), and that in September at the beginning of the rainy season (warmer temperatures).

\subsubsection{Distribution of patients by age and sex}

Table 1 presents different age range comparing to the gender.

Table 1. Distribution of patients per age and sex

\begin{tabular}{ccccccc}
\hline Range age (months) & \multicolumn{4}{c}{ Sex } & \multicolumn{3}{c}{ Total } \\
\cline { 2 - 8 } & \multicolumn{2}{c}{ Male } & \multicolumn{2}{c}{ Female } & N & $\%$ \\
$0-11$ & 101 & 31.17 & 95 & 29.32 & 196 & 60.5 \\
$12-23$ & 57 & 17.59 & 34 & 10.50 & 91 & 28.10 \\
$24-35$ & 15 & 4.63 & 8 & 2.47 & 23 & 7.10 \\
$36-47$ & 4 & 1.23 & 5 & 1.54 & 9 & 2.8 \\
$48-71$ & 2 & 0.62 & 3 & 0.93 & 5 & 1.5 \\
\hline Total & $\mathbf{1 7 9}$ & $\mathbf{5 5 . 2 4}$ & $\mathbf{1 4 5}$ & $\mathbf{4 4 . 7 6}$ & $\mathbf{3 2 4}$ & $\mathbf{1 0 0 \%}$ \\
\hline
\end{tabular}

Of the total patient population, 179 sick children (55.24\%) were male and 145 (44.76\%) female. This study also recorded a predominance of cases in the $0-11$ month age group, with 196 cases $(60.50 \%)$, followed by $28.09 \%$ (91 cases) in the 12-23 month age group, 24 cases $(7.41 \%)$ in the $24-35$ month age group, 8 cases $(2.46 \%)$ in the $36-47$ month group and 5 cases $(1.54 \%)$ in the $48-71$ month group. The average age of children hospitalized for acute diarrhea was 12 months and 4 days with extremes ranging from 0-71 months.

\subsection{Clinical and etiological characteristics}

\subsubsection{Pathogen relationship and patient age}


The search for causative agents of diarrhea was carried out on 183 cases representing $56.48 \%$ of the population under study and the isolated pathogens were distributed by age group.

Table 2. Distribution of patients per isolated etiological agent and age range

\begin{tabular}{|c|c|c|c|c|c|c|}
\hline \multirow{2}{*}{$\begin{array}{l}\text { Age range } \\
\text { (months) }\end{array}$} & \multicolumn{2}{|c|}{ Viruses } & \multirow[b]{2}{*}{ Bacteria } & \multirow[b]{2}{*}{ Parasites } & \multirow[b]{2}{*}{ Yeasts } & \multirow[b]{2}{*}{ Total } \\
\hline & Rotavirus & NIV & & & & \\
\hline $0-11$ & 61 & 25 & 32 & 27 & 8 & 153 \\
\hline $12-23$ & 23 & 12 & 19 & 14 & 2 & 70 \\
\hline $24-35$ & 2 & 3 & 5 & 6 & 0 & 16 \\
\hline $36-47$ & 2 & 0 & 5 & 1 & 1 & 9 \\
\hline $48-71$ & 0 & 0 & 0 & 0 & 0 & 0 \\
\hline Total & 88 & 40 & 61 & 48 & 11 & 324 \\
\hline
\end{tabular}

The analysis of the distribution of isolated and/or identified etiological agents by age group shows a predominance of viral infection, 128 cases $(69.94 \%)$, of which 88 cases of rotavirus represent $48.08 \%$ of patients. Children under 12 months of age were the most affected by rotavirus diarrhea (33.3\%), followed by those aged 12-23 months (12.56\%). Bacterial, parasitic and fungal (yeast) infections were also more common in children under 12 months of age.

\subsubsection{Distribution of isolated pathogens by sampling period}

The analysis of the monthly distribution of pathogens isolated or identified throughout 2015 (Table 3) shows a peak in March, June and September for rotaviruses.

Table 3. Monthly distribution of isolated and/or identified etiological agents

\begin{tabular}{|c|c|c|c|c|c|}
\hline \multirow{3}{*}{ Months } & \multicolumn{2}{|c|}{ Viruses } & \multirow{3}{*}{ Bacteria } & \multirow{3}{*}{ Parasites } & \multirow{3}{*}{ Yeasts } \\
\hline & & & & & \\
\hline & Rotavirus & NIV & & & \\
\hline January & 5 & 2 & 3 & 10 & 2 \\
\hline February & 6 & 2 & 0 & 4 & 1 \\
\hline March & 14 & 3 & 4 & 6 & 4 \\
\hline April & 5 & 3 & 2 & 3 & 0 \\
\hline May & 6 & 1 & 2 & 3 & 0 \\
\hline June & 12 & 12 & 14 & 4 & 1 \\
\hline July & 8 & 4 & 12 & 5 & 0 \\
\hline August & 7 & 5 & 8 & 3 & 0 \\
\hline September & 16 & 5 & 8 & 4 & 1 \\
\hline October & 1 & 1 & 6 & 1 & 0 \\
\hline November & 3 & 1 & 1 & 2 & 2 \\
\hline December & 5 & 1 & 1 & 3 & 0 \\
\hline Total & 88 & 40 & 61 & 48 & 11 \\
\hline
\end{tabular}

Legend : NIV : Non identified viruses

As observed in the table, there is a peak in June for NIV and bacteria, another peak in January for parasites and March for yeasts. 


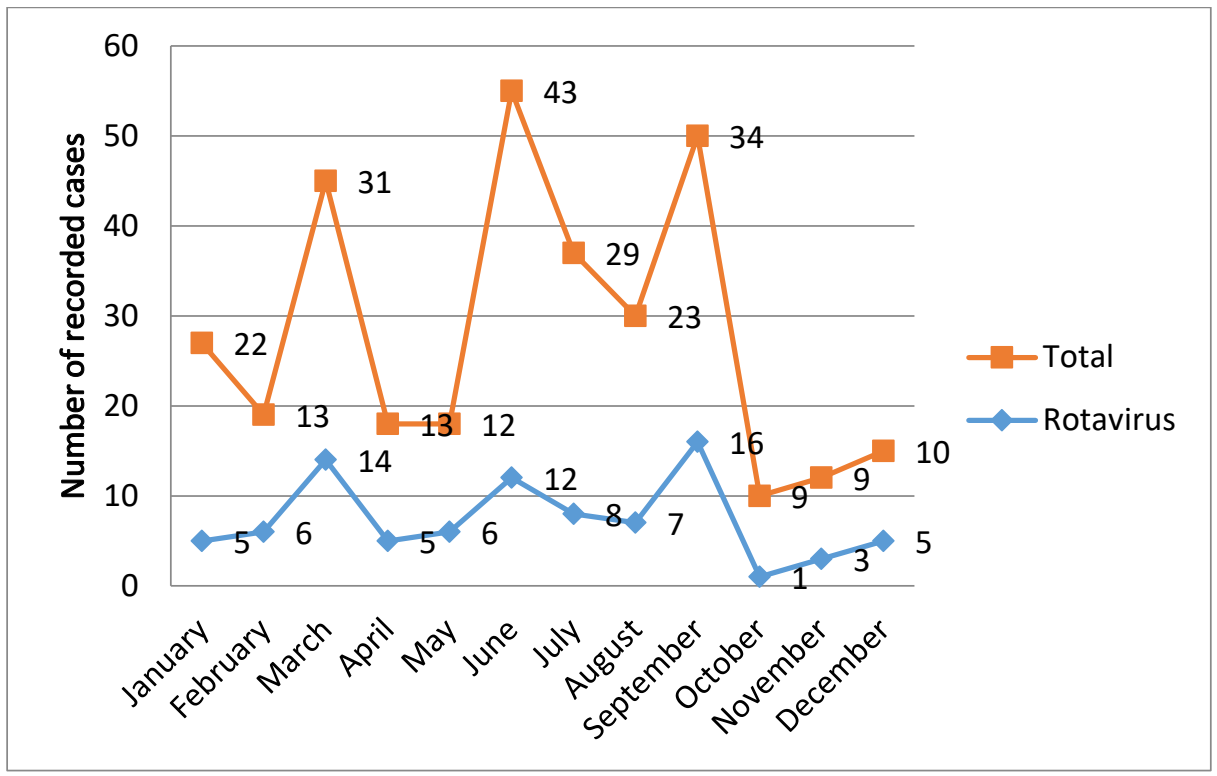

Figure 2. Evolution of the distribution of patients according to the rotavirus etiological agents identified during 2015.

In general, rotaviruses contribute significantly to the total number of cases recorded, particularly in March and September, 2 months of the rainy season, but also in June, a month of the dry season (Figure 2).

\subsubsection{Relationship between isolated pathogens and clinical signs}

The analysis of clinical signs in relation to isolated pathogens reveals, in decreasing numerical order of importance, vomiting, fever probably associated with it, physical asthenia, agitation occurring only in cases of rotavirus infection (Figure 3).

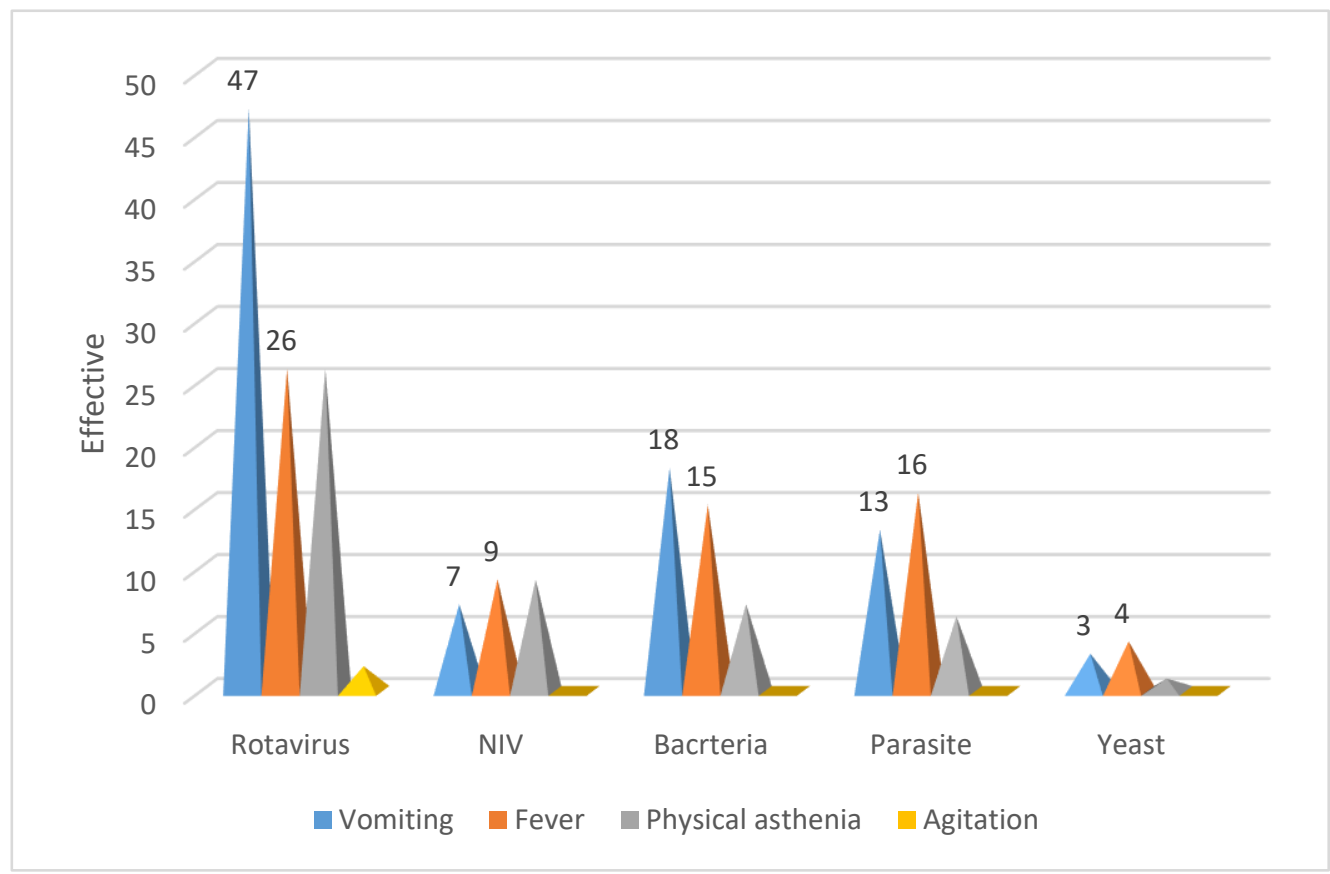

Figure 3. Distribution of patients by clinical signs and germs involved 
The frequency of the following clinical signs: vomiting, fever, physical asthenia and agitation as clinical signs associated with diarrhea were more frequent in children infected with rotavirus.

\subsection{Relationship between pathogen association and clinical signs}

The distribution of cases following clinical signs along with different combination of pathogens is described in the figure below.

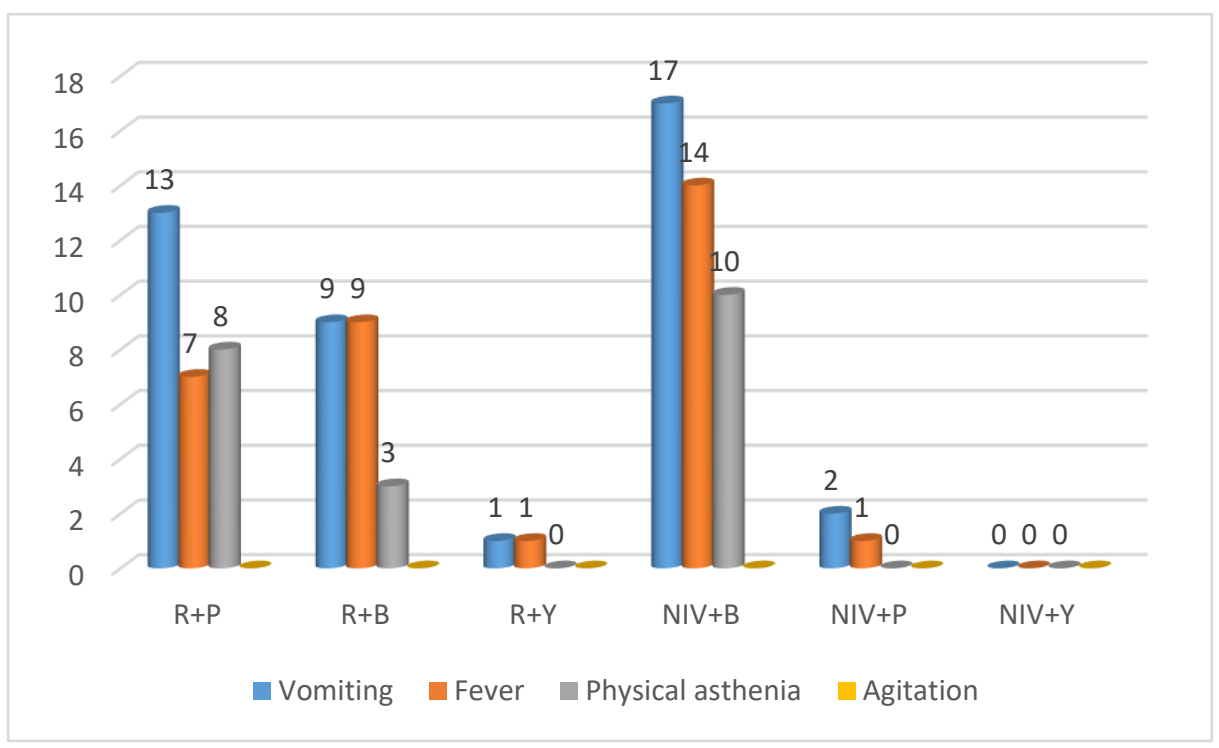

Figure 4. Distribution of cases according to clinical signs and associations of the germs involved. Legend: R: Rotavirus; B: Bacteria; NIV : Non identified viruses; P: Parasite; Y: Yeast.

The most frequent associations of pathogens in descending order are NIV/bacteria, Rotavirus/bacteria and Rotavirus/parasites (Figure 4). The associations in which rotaviruses are involved, considering all clinical signs, represent 51 cases $(27.87 \%)$. There are two distinct classes of pathogen associations: rotavirus or NIVs, associated with other agents. There does not appear to be associations between other pathogens isolated from this population. In general, the clinical signs are distributed in decreasing order as follows: 42 cases of vomiting (23\%), 32 cases of fever (17.5\%), 21 cases of physical asthenia (11.5\%), no case of agitation.

\subsection{Relationship between isolated pathogens and stool frequency}

The relationship between isolated pathogens and stool frequency is shown in Figure 5. 


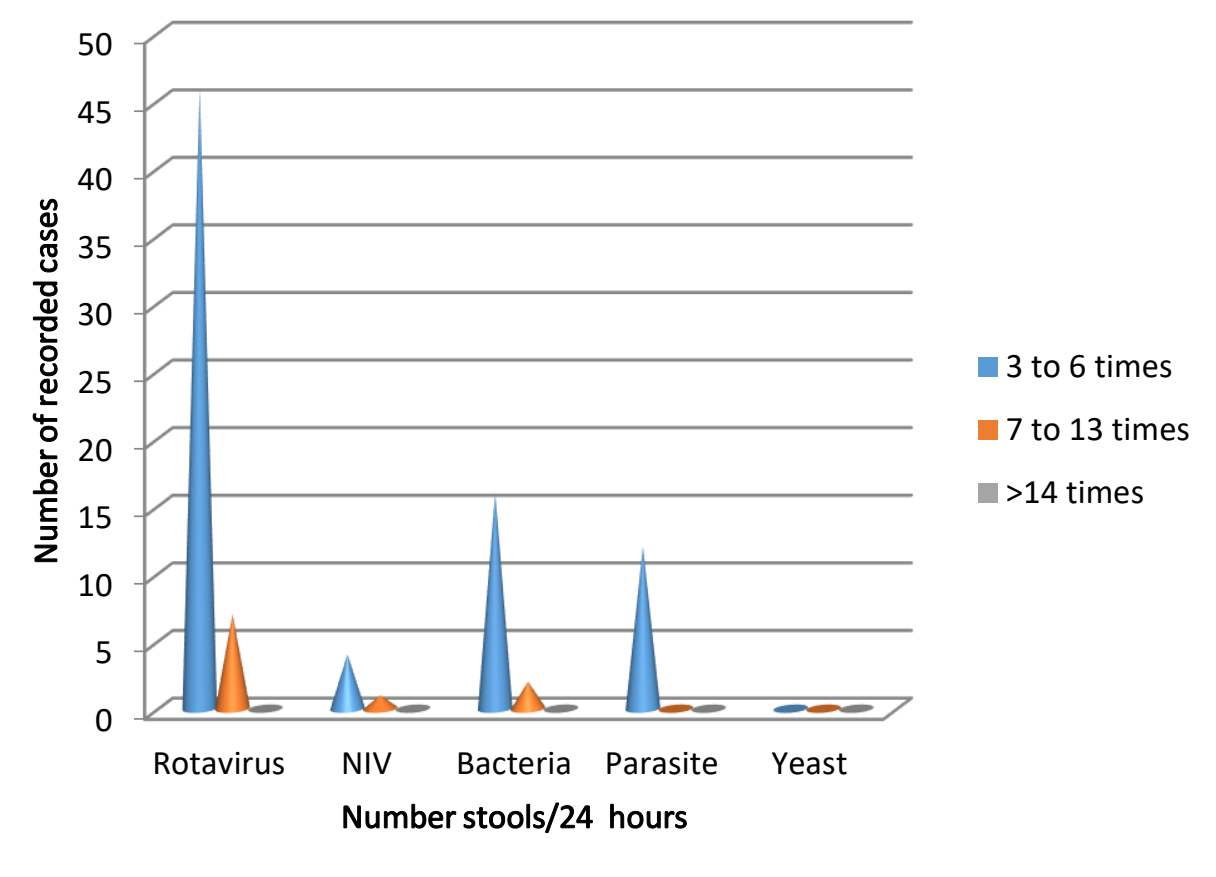

Figure 5. Distribution of cases according to the pathogens isolated and the frequency of stools/day. Legend: R: Rotavirus; B: Bacteria; NIV : Non identified viruses; P: Parasite; L: Yeast

Statistical analysis does not provide a significant relationship between isolated pathogens and stool count $/ 24 \mathrm{~h}\left(\mathrm{X}^{2}=3.4352, \mathrm{df}=8, \mathrm{p}\right.$-value $\left.=0.9042\right)$. However, the prevalence of rotavirus infections can be observed on the frequency of stool in 24 hours, a value that does not exceed 13 times. Overall, considering all stool classes/24 hours, 54 cases associated with rotavirus $(29.51 \%), 18$ cases associated with bacteria $(9.84 \%), 12$ cases with parasites $(6.56 \%), 5$ cases with NIVs (2.73\%) and 4 cases with yeasts $(2.19 \%)$ are observed. The only case reported with a 24-hour frequency greater than 14 hours is associated with rotaviruses (fig. 5). The frequency classes of stool/24 hours are distributed in decreasing order according to: 3 to 6 times, 82 cases (44.81\%), 7 to 13 times, 10 cases (5.5\%), 14 times and more, 1 case $(0.55 \%)$.

Figure 6 displays the relationship between the association of different pathogens and the frequency of stools. 


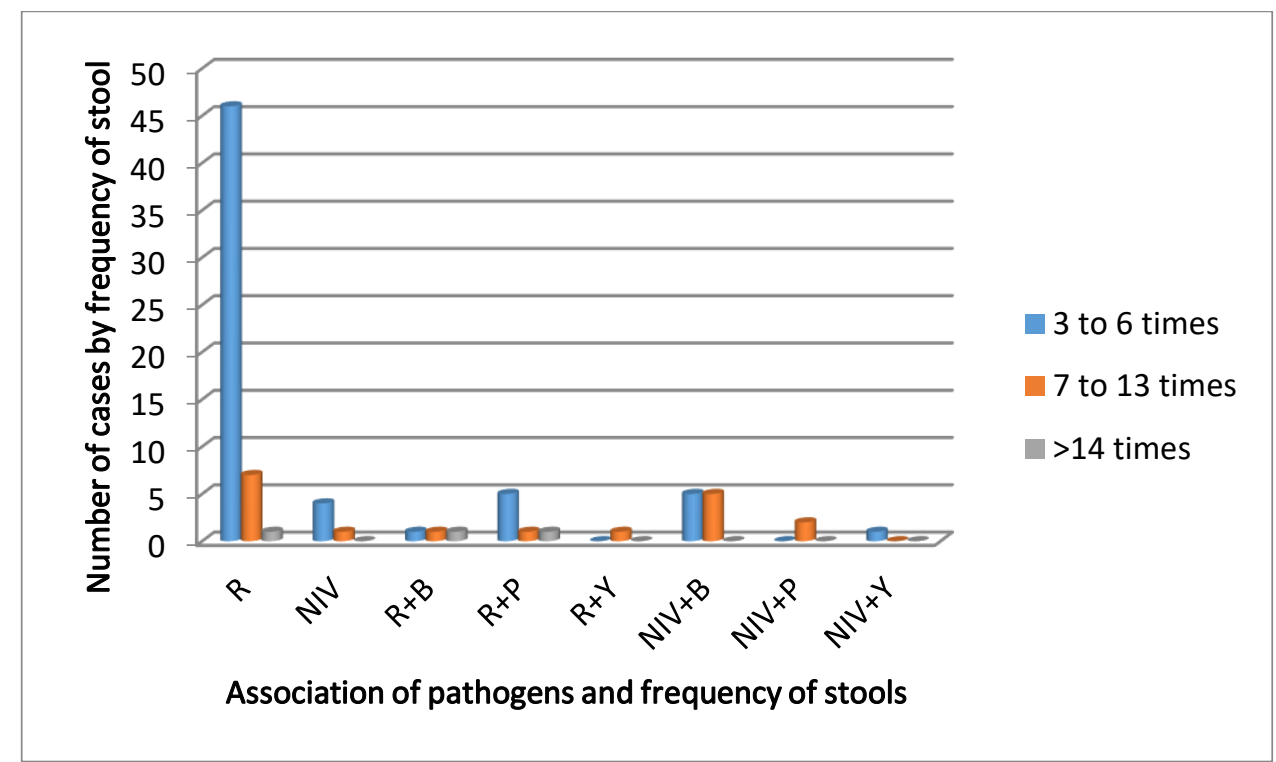

Figure 6. Distribution of cases according to the association of pathogens isolated and the frequency of stools/day. Legend: R: Rotavirus; B: Bacteria; NIV : Non identified viruses; P: Parasite; Y: Yeast

The analysis of this parameter (Figure 6) also reveals, that the distribution of stool frequencies in 24 hours in the following decreasing order, all associations combined: 3 to 6 times, 62 cases (33.88\%), 7 to 13 times, 18 cases (9.84\%), 14 times and more, 3 cases $(1.64 \%)$. This last frequency class of stool/24 is entirely attributed to rotavirus. Similarly, pathogen associations, taken in isolation, reveal the predominance of stool cases (65 cases) due to rotavirus alone or in association with other isolated pathogens (33.88\%), 18 cases due to NIV alone or in association with other pathogens $(9.84 \%)$. The presence of rotavirus or unidentified viruses at the time of infection in patients may justify the high rate of persistent fever in the sample (Figure 6). The presence of more pathogens indicates a highly significant relationship between stool count/24h and associations of isolated pathogens $\left(\mathrm{X}^{2}=30.004, \mathrm{df}=14, \mathrm{p}\right.$-value $\left.=0.007621\right)$.

\subsection{Relationship between pathogen agents and stool appearance}

Figure 7 presents the relationship between pathogen agents and stool appearance.

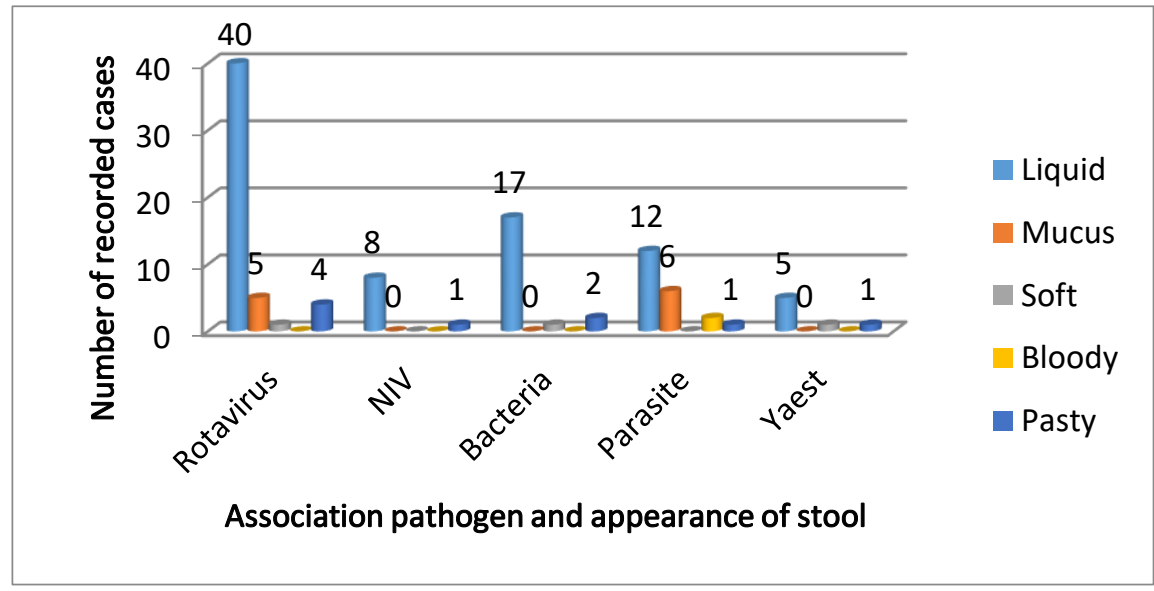

Figure 7. Distribution of cases by isolated pathogens and stool appearance. Legend: NIV : Non identified viruses 
There is a statistically significant relationship between different aspects of stool and isolated pathogens $\left(\mathrm{X}^{2}=24.58, \mathrm{df}=12, \mathrm{p}\right.$-value $\left.=0.01694\right)$. Most stools are liquid (Figure $7)$, regardless of the pathogen isolated, the other aspects being poorly represented $(<10 \%)$.

Figure 8 presents the relationship between pathogen agents (different associations of pathogens) and stool appearance.

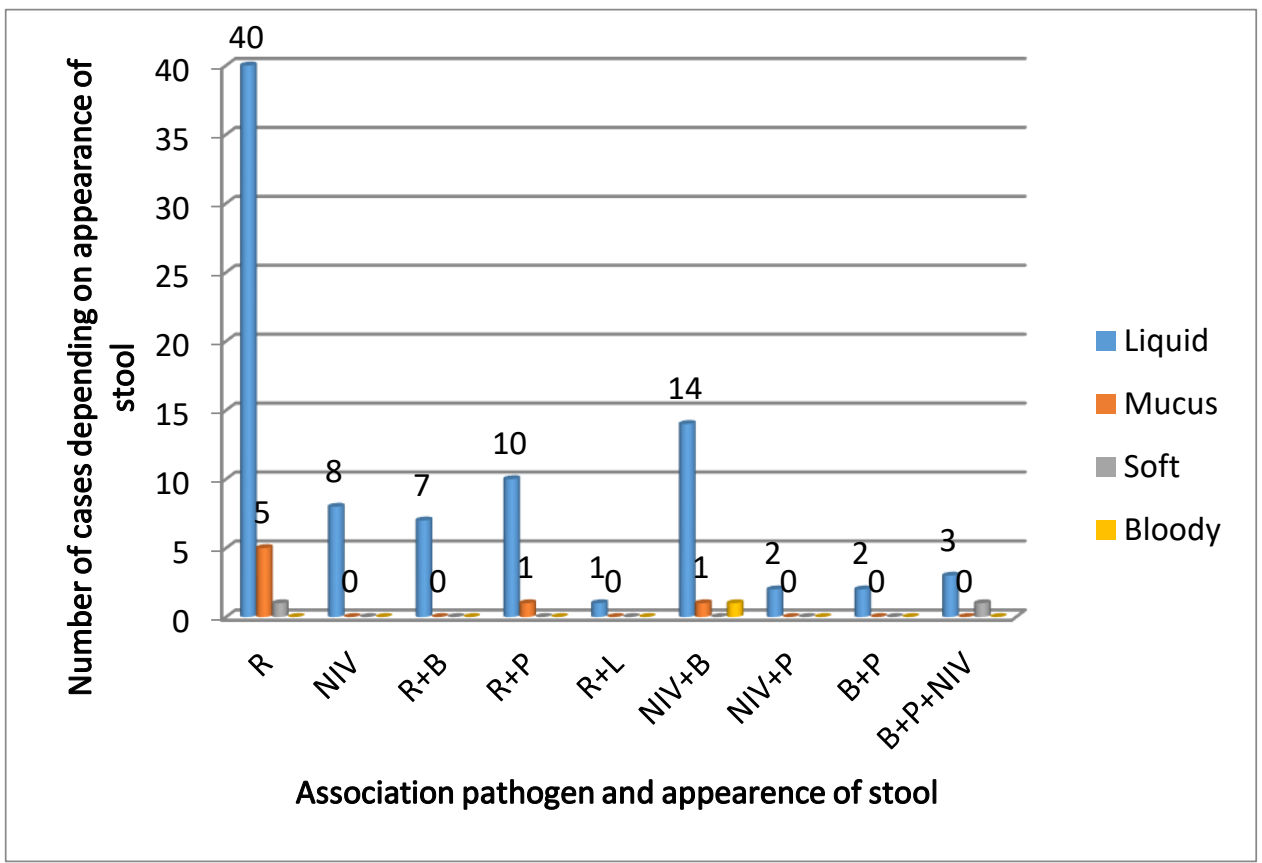

Figure 8. Distribution of stool appearance cases by association of isolated pathogens. Legend: R: Rotavirus; B: Bacteria; NIV : Non identified viruses; P: Parasite; L: Yeast

The results do not show a significant relationship between different aspects of stool and pathogen associations $\left(\mathrm{X}^{2}=23.55, \mathrm{df}=32\right.$, $\mathrm{p}$-value $\left.=0.8603\right)$. However, it can be noted that the liquid aspect of the stool predominates in all associations of isolated pathogens, while the other aspects of the stool remain very weak (Figure 8). Furthermore, it was observed that the liquid aspect of the stool of patients infected with rotavirus alone, 40 cases $(21.86 \%)$, or associated with other pathogens, remains significantly more important than the other aspects of the stool: Rotavirus + bacteria, 8 cases $(4.37 \%)$, rotavirus + parasites, 12 cases $(6.56 \%)$, rotavirus + yeasts, 1 case $(0.55 \%)$.

Regardless of the association of pathogens, the presence of viruses is clinically observed, particularly rotavirus at $9.83 \%$ of isolated cases, and $31.69 \%$ of cases in which rotavirus occurs. The NIV associated with bacteria has a significant soft stool frequency, 14 cases $(7.65 \%)$. 


\subsection{Relationship between isolated pathogens and state of dehydration}

Figure 9 presents the distribution of acute diarrhea cases per isolated pathogens and the state of dehydration.

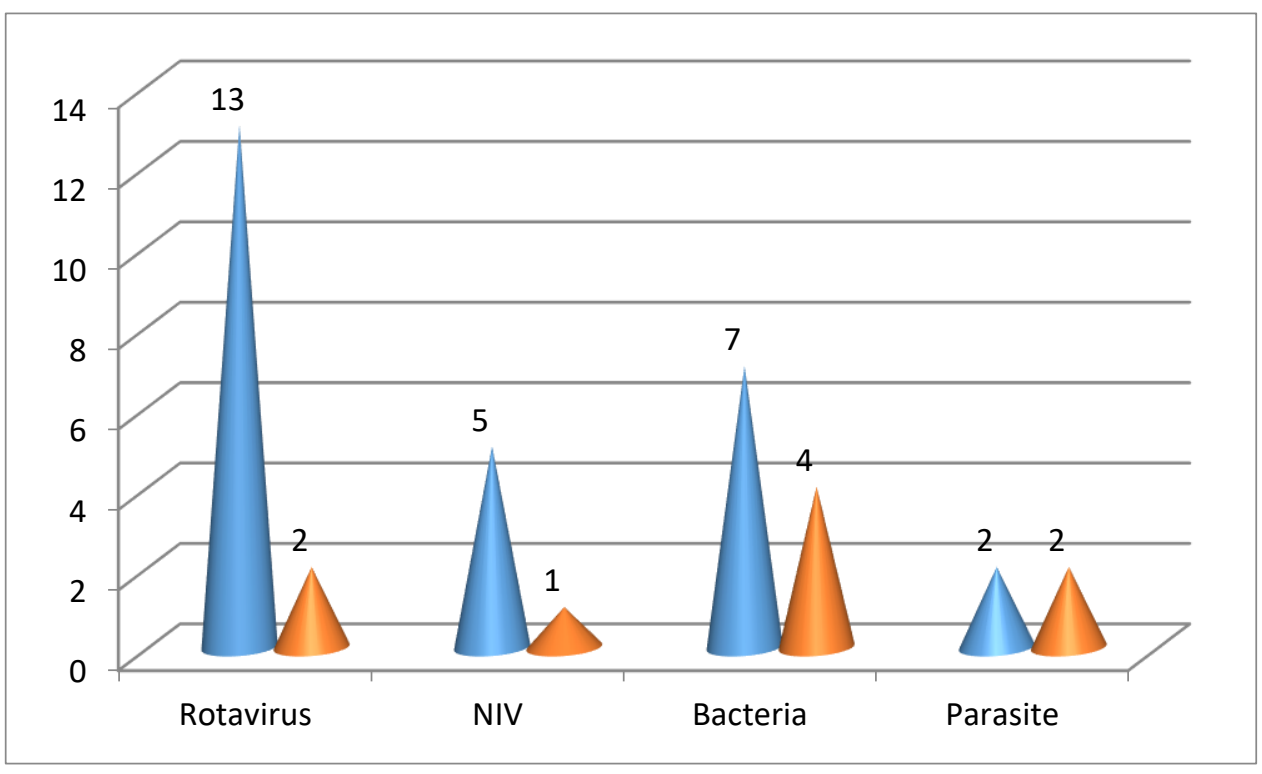

Figure 9. Distribution of acute diarrhea cases by isolated pathogens and state of dehydration. Legend: NIV : Non identified viruses, B: Moderate dehydration, C: Severe dehydration.

Severe dehydration (C) in hospitalized patients appears to be mainly associated with the presence of bacteria, while moderate dehydration (B) with rotavirus (Figure 9). Moderate dehydration by viruses accounts for $13.85 \%$ of cases compared to $4.92 \%$ of severe cases due to bacteria and parasites combined; severe dehydration is observed at $1.64 \%$ and $3.28 \%$, respectively due to viruses and bacteria as well as parasites. The Chi-square test does not provide a statistically significant relationship between isolated pathogens and dehydration status $\left(\mathrm{X}^{2}=3,402, \mathrm{df}=3, \mathrm{p}\right.$-value $\left.=0.3337\right)$.

In general, there are more cases of type B dehydration, 27 cases representing $14.75 \%$, than of severe dehydration, 3 cases (1.64\%). The low rate of severe dehydration can indicate good patient management during hospitalization.

The distribution of acute diarrhea cases according to the association of isolated pathogens and state of dehydration. Is presented in Figure 10 below. 


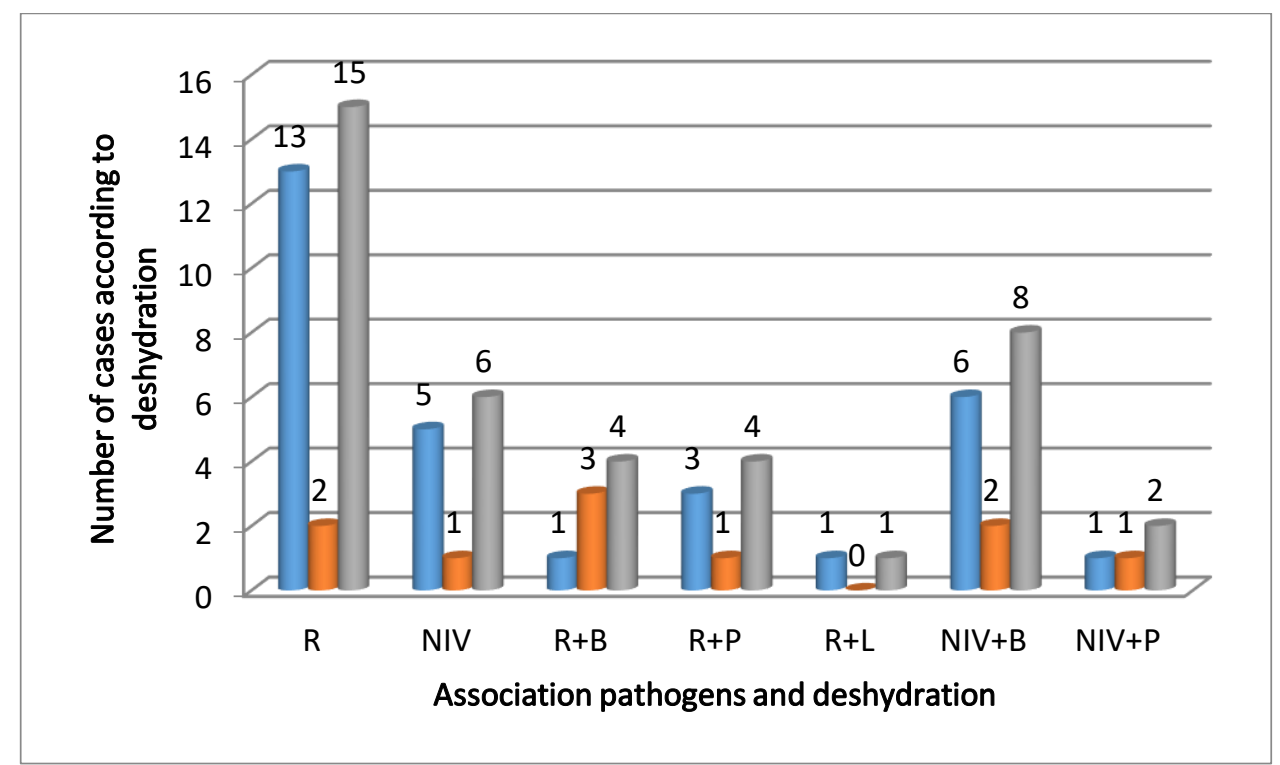

Figure 10. Distribution of acute diarrhea cases according to the association of isolated pathogens and state of dehydration.

Figure 10 indicates that there is no statistical relationship between dehydration status and the associations of the isolated pathogens $\left(X^{2}=7.6444, \mathrm{df}=6, \mathrm{p}\right.$-value $\left.=0.2653\right)$.

\section{Discussion}

\subsection{Epidemiological, clinical and etiological findings}

\subsubsection{Monthly distribution of isolated pathogens}

The findings of this study show that pathogens were isolated throughout the year. However, there is a peak in March, June and September for rotaviruses, June for NIVs (unidentified viruses) and bacteria, January for parasites and March for yeasts. The dry season (January and June) provided conditions conducive to the multiplication of the causative agents of diarrhea (rotavirus and other viruses, bacteria and parasites) compared to the rainy season (March, September). This justifies the peak during the dry season. Several studies attested that in hospitals or daycare centres, the frequency of rotavirus infections can range between 50 and $80 \%$, especially in winter, which corresponds to the dry season in DRC $[8,15-19]$.

\subsubsection{Distribution by age and germs involved}

The search for diarrhea causative agents was carried out in only $56.48 \%$ of cases. However, there is a predominance of viral infection (69.94\%), including rotaviruses, which have been isolated and identified in $48.08 \%$ of cases. Children aged $0-11$ months were the most affected by rotavirus diarrhea, with 61 cases (33.33\%). The same applies to infections with other causative agents of diarrhea. As age increases, the proportion of infections with the causative agents of diarrhea decreases. This could be explained by the development of the child's immune system and the introduction of antibodies specific to the germs responsible for diarrhea after repeated infections [8,21-22]. This would explain the decrease in rotavirus incidence in children aged $12-24$ months observed in the findings.

The results of this investigation are similar to those of Kabuya et al. [1] who reported a rate of $49.22 \%$ rotavirus infection in children aged 0-12 months. The maximum number of cases reported in children aged 0-12 months (76.1\%) was also reported by Jiang et al. [2], Salou [8], Huilan [23]; Offit et al. [24]. These studies reported that rotavirus infection 
mainly affected children under two years of age with a peak incidence in children aged 611 months. They justified this observation by the protective effect of maternal antibodies in 6-month-old breastfeeding children and the development of natural immunity after repeated infections in children over two years old.

Djénéba [22] also reported that the incidence of diarrhea due to rotavirus was higher in children aged 2-11 months (38.71\%) compared to those aged 12-24 months (12.5\%). Moreover, Cardoso et al. [25] reported that rotavirus detection was high in children under 12 months of age compared to those of 24 months of age and decreased sharply after two years.

\subsubsection{Distribution of patients according to clinical signs and germs involved}

The most common clinical signs namely vomiting, fever, physical asthenia and agitation were found significant in children from whom rotaviruses were isolated. (Figure 3). These observations are similar to Kabuya et al. [1], who reported as well high proportions of vomiting, fever and lethargy in infants infected with rotavirus compared to those infected with other germs.

\subsection{Distribution of patients according to clinical signs and association of germs involved}

Vomiting was more frequent in virus, bacteria, and rotavirus-parasite combinations, while fever and physical asthenia were more common in virus-bacteria combinations (Figure 4). Vomiting ( $1^{\text {st }}$ symptom preceding diarrhea), watery stools, moderate fever (of very variable intensity), dehydration, electrolyte imbalance and metabolic acidosis often characterize rotavirus infection [26]. However, it should be noted that this clinical picture is not specific to rotavirus infection only; other etiological agents of diarrhea, such as bacteria (Salmonella, Campylobacter, Yersinia enterolitica, enteropathogenic Escherichia coli, Staphylococcus aureus, etc.) or parasites may reflect the same clinical picture.

\subsection{Frequency of stool and germs involved}

By comparing the group of children infected with rotavirus and the group of children infected with other germs, it was observed that children in the first group passed more stool (Figure 5) than those infected with other germs. Nevertheless, the analysis of the Chi-square test does not reveal a significant statistical relationship.

The fact that the Chi-square test did not establish a significant statistical relationship suggests that in addition to rotavirus, other germs may also be responsible for more frequent stools. Kabuya et al, [1], reported $59.6 \%$ of children infected with rotavirus and having passed a number of stools $\geq 6$ compared to $41.6 \%$ in the group of children infected with other germs and having passed the same number of stools.

\subsection{Relation of stool frequency and association of isolated pathogens}

Groups of children infected with rotavirus alone had more stools (3-13 stools/day) (Figure 6) compared to those of cases of germ associations. When comparing data on the relationship between the association of germs and stool frequency, it was observed that the virus-bacteria association caused frequent stool (7-13 stools/day) compared to other associations. The analysis of the $\mathrm{X}^{2}$ test indicated a highly significant relationship between the number of stools/24h and associations of isolated pathogens. The analysis of these findings suggests that in addition to rotaviruses, the combination of rotaviruses or other viruses and bacteria can also cause frequent stools. 


\subsection{Relationship between the physical aspect of the stool and the germs involved}

Liquid stools were very common in the group of individuals infected with rotavirus (40 cases), followed by those infected with bacteria (17 cases) (Figure 7), while mucus stools were predominant in parasite infections. Statistical analysis showed a significant relationship between different aspects of stool and isolated pathogens. Indeed, the infection with rotaviruses or certain bacteria (Salmonella, Campylobacter, and Yersinia enterolitica) is often characterized by watery stools [1,26].

\subsection{Relation of physical appearance of stool and association of isolated pathogens}

This study shows that liquid stools characterize rotavirus infections (40 cases), virusbacteria association (14 cases) and rotavirus-parasites (10 cases) (Figure 8), whereas mucus stools are characteristic of rotavirus infections. Statistical analysis does not show a significant relationship between the different aspects of stool and associations of isolated germs.

\subsection{Relationship between the state of dehydration and the germs involved}

Moderate dehydration characterizes rotavirus infections, followed by bacterial infections, while severe dehydration characterizes bacterial infections (Figure 9). Nevertheless, the $\mathrm{X}^{2}$ test does not provide a statistically significant relationship between isolated pathogens and dehydration status. Kabuya et al. [1], reported that children were 6 times more likely to experience moderate or severe dehydration than those infected with other germs.

\subsection{Relationship between dehydration status and association of the pathogens involved}

Moderate dehydration was much more common in rotavirus infections or virus-bacteria combinations, while severe dehydration by rotavirus-bacteria combinations was characterized (Figure 100). The $X^{2}$ analysis indicated that there is no statistical relationship between dehydration status and associations of isolated germs.

\section{Conclusion}

Acute rotavirus diarrhea is present in Kinshasa city and particularly affects children under 12 months of age. Infections by the causative agents of diarrhea are endemic throughout the year and do not appear to be exclusively reserved for the dry season. The higher proportion of vomiting, fever, physical asthenia and agitation was higher in rotavirus infections. In addition, vomiting was more common in bacterial-virus and rotavirusparasite combinations, while fever and physical asthenia were more common in virusbacterial combinations.

Cases of rotavirus infections were more likely to pass stool compared to those of infections due to other germs. However, the statistical analysis did not show a significant relationship. In addition, virus-bacteria associations caused abundant stools (7-13/day) compared to other associations. Moderate dehydration characterized cases of rotavirus and bacterial infections, while severe dehydration was more common in cases of bacterial infections. Furthermore, virus-bacteria associations were characterized by moderate dehydration while rotavirus-bacteria association was characterized by severe dehydration; as in the cases of previous associations.

Subsequent studies should establish a relationship between the etiological agents of diarrhea and the identification of bacterial species and rotavirus strains.

\section{References}

[1] Kabuya SM, Makuku, Mulangu A., Mutombo, Makan MP, Kawawa SE, Kasongo K, Kabamba M., Okitotsho W.,Numbi LO. Etude épidemio-clinique des diarrhées aiguës à rotavirus chez les nourrissons à l'hôpital Jason-Sendwe de Lubumbashi en République Démocratique du Congo. Pam. Afr. Med. J. 2015, 21 : 113.

[2] Jiang B, Gentsch JR, Glass RI. The role of serum antibodies in the protection against rotavirus disease: an overview. Clin Infect Dis. 2002; 34(10):1351-1361. 
[3] Brasseur D., Goyens P. Diarhée chez les enfants dans les pays en voie en développement. Gastoentérologie pédiatrique. Flammarion, $2^{\text {ème }}$ edition, Paris 2000.

[4] Barets A., Florat D. Diarrhée aigue et déshydratation chez les nourrison et l'enfant. Rev. Prat 2005, 55 : $2065-2069$.

[5] Imbert P. Prise en charge de la diarrhée aigue en milieu tropical. Rev Med $2001 ; 61: 226-230$.

[6] Podewils LJ, Mintz ED, Nataro JP, Parashar UD. Acute, Infections diarrhea among children in developing countries. Sem Pediatric Infect Dis, 2004; 15:155-168.

[7] Thapar N., Sanderson IR. Diarhea in children: an interface between developing countries. Lancet. 2004 Feb 21; 363 (9409): 64153.

[8] Salou NR. Les diarrhées de l'enfant en pratique de la ville à Ouagadougou : Etudes épidémiologiques, cliniques étiologiques et prise en charge. Thèse de Doctorat, Université de Ouagadougou, Unité de formation et de recherche en Sciences de la santé (UFR/SDS) au Burkina-Faso, 2004, 66p.

[9] OMS. Le traitement de la diarrhée : manuel à l'usage des médecins et autres personnels de santé qualifiés. 2006, 4è rev.

[10] Nganda YL, Tamfum LM, Foemi OK, Bosmans E. Etiologie des gastroentérites aiguës infantiles à Kinshasa. Ann Soc Belge Med Trop. 1986; 66:331-7.

[11] Jagai JS, Sarkar R, Castronovo D, Kattula D, McEntee J et al. Seasonality of Rotavirus in South Asia: A Meta-Analysis Approach Assessing Associations with Temperature, Precipitation, and Vegetation Index. PLoS ONE. 2012 May 31; 7(5):e38168.

[12] Bok K, Castagnaro N, Borsa A, Nates S, Espul C, Fay O, Fabri A, Grinstein S, Miceli I, Matson DO, Gómez JA. Surveillance for rotavirus in Argentina. J Med Virology. 2001 Sep;65(1):190-198.

[13] MICS-RDC. Rapport final. Province du Katanga ; 2011. Accessible à www.unicef.org/drcongo/french/MICS_RDC_2010.pdf et consulté le 12 janvier 2014.

[14] Esona MD, Armah GE, Steele AD. Molecular epidemiology of rotavirus infection in Western Cameroon. J Trop Pediatr. 2003 Jun;49(3):160-163.

[15] Glass RI, Lew JF, Gangarosa RE, LeBaron CW, Ho MS. Estimates of morbidity and mortality rates for diarrheal diseases in American children. J Pediatr. 1991 Apr; 118(4 Pt 2):S27-33.

[16] López-de-Andrés A, Jiménez- García R, Carrasco-Garrido P, Alvaro-Meca A, Galarza PG, de Miguel AG. Hospitalizations associated with rotavirus gastroenteritis in Spain, 2001-2005. BMC Public Health. 2008; 8:109.

[17] Zeng M, Chen J, Gong ST, Xu XH, Zhu CM, Zhu QR. Epidemiological surveillance of norovirus and rotavirus diarrhea among outpatient children in five metropolitan cities. Chinese J Pediatr. 2010; 48(8):564-70.

[18] Zuccotti G, Meneghin F, Dilillo D, Romanò L, Bottone R, Mantegazza C, Giacchino R, Besana R, Ricciardi G, Sterpa A, Altamura N, Altamura N, Andreotti M, Montrasio G, Macchi L, Pavan A, Paladini S, Zanetti A and Radaelli G. Epidemiological and clinical features of rotavirus among children younger than 5 years of age hospitalized with acute gastroenteritis in Northern Italy. BMC Infect Dis. 2010; 10:218.

[19] Kargar M, Najafi A, Zandi K, Hashemizadeh Z. Genotypic distribution of rotavirus strains causing severe gastroenteritis in children under 5 years old in Borazjan, Iran. African J Microbiol Res. 2011; 5(19):2936-41.

[20] Mbadiko CM, Bongo GN, Mbuyi GK, Kemfine LL, Tshiama CR, Nsutier OK, Kanika JM, Ngando TB, Bomoi JM, Bamvingana Ck and Mutambel'Hity SN. Epidemiological and Clinical Profiles of Children Aged 0-71 Months Suffering from Acute Diarrhea at Kalembe-lembe Pediatric Hospital in Kinshasa City, Democratic Republic of the Congo. Asian J Adv Res Reports, 2019, 4(2);111

[21] Sanou I, Kam KL,Tougouma A, Sangare L, Nikiema JPH, Kouetaf F, Dao L, Sawadogo SA, Soudre RB. Diarrhées aigües de l'enfant: Aspects épidémiologiques, cliniques et évolutifs en milieu hospitalier pédiatrique à Ouagadougou. Médecine d'Afrique Noire, 1999, 46 (1).

[22] Djénéba O. Prévalence des infections à Rotavirus, Adénovirus et parasites entériques chez les enfants VIH-séropositifs et VIH séronégatifs de 0-5ans au centre médical saint Camille. Mémoire de DEA (Diplôme d'Etudes Approfondies), Université de Ouagadougou, 2006.

[23] Huilan S, Zhen LG, Mathan MM, Matthew MM, Olarte J, Espejo R, Maung UK, Ghafoor MA, Khan MA and Sami Z. Etiology to acute diarrhea among children in developing countries; A multi-centre study in five countries. Bull World Health Organ 1991; $69: 549-5$

[24] Offit PA. Host factors associated with protection against rotavirus disease: the skies are clearing. J Infect Dis. 1996; 174(Suppl 1):S59-S64.

[25] Cardoso DDP., Soares CMA, Souza MBL, Azevedo MSP, Martins RMB, Queiroz DAO, Brito W.M.ED, Munford V., Racz M.L.,( 2003). Epidemiological features of rotavirus infection in Goiânia, Goiás, Brazil, from 1986 to 2000. Mem Inst Oswaldo Cruz, Rio de Janeiro, 98(1): 25-29.

[26] Haffaf AFZ. Gastro-entérite aigue du nourrisson. Mémoire de fin d'étude, Université Abour Bekr belkaid, Algérie, 2014. 